\title{
Differential Diagnosis of COVID-19 Enanthema
}

\author{
Rochman Mujayanto ${ }^{1} \quad$ Recita Indraswary ${ }^{2}$ \\ ${ }^{1}$ Department of Oral Medicine, Faculty of Dentistry, Universitas \\ Islam Sultan Agung, Central Java, Indonesia \\ ${ }^{2}$ Department of Oral Biology, Faculty of Dentistry, Universitas Islam \\ Sultan Agung, Central Java, Indonesia
}

Eur J Dent:2020;14(suppl S1):S179-S181

Coronavirus disease 2019 (COVID-19) is a disease that has become a pandemic in the world with very high transmission rates. COVID-19 is caused by coronavirus which initially infects animals (bats, camels, birds, and anteater). This virus is transmitted by animals to humans, then transmitted from human to human. Coronavirus that infects humans causes acute respiratory distress syndrome (ARDS). ${ }^{1,2}$

COVID-19 infection begins with the invasion of severe acute respiratory syndrome coronavirus 2 (SARS-CoV-2) in host cells. SARS-CoV-2 has a life cycle in host cells to be able to replicate so that viral load will increase and cause symptoms of the disease. The life cycle of SARS-CoV-2 in host cells can be divided into attachment, endocytosis, membrane fusion phases, biosynthesis, and maturation. The presence of SARS-CoV-2 in the host body will trigger a series of immune responses that involve complex intersection signaling. ${ }^{1-4}$

\section{Transmission of Disease}

SARS-CoV-2 is transmitted through saliva by droplet, airborne, and aerosol transmission. Droplets are formed when COVID-19 sufferers talk, cough, or sneeze causing saliva to splash around $( \pm 1 \mathrm{~m})$. SARS-CoV-2 in saliva can last 29 days. SARS-CoV-2 droplet transmission can occur directly or indirectly. ${ }^{5,6}$ Direct droplet transmission occurs when healthy people are splashed with oral fluid when in close contact with an infected patient. Indirect droplet transmission occurs when healthy people touch the patient or the surface of objects or objects around the infected patient. Droplet infectious fluid will evaporate into a lighter fluid and spread through the air (airborne) up to $10 \mathrm{~m}$ from the initial location of the droplet. This if inhaled, healthy people become infected. Aerosol transmission is an airborne transmission that occurs indoors and SARS-CoV-2 can last for 3 days in a closed room. Aerosol transmission causes SARS-CoV-2 to infect large numbers of people at one time and in a fast time. ${ }^{5-8}$

\begin{abstract}
Address for correspondence Rochman Mujayanto, drg, Sp. PM, Department of Oral Medicine, Faculty of Dentistry, Universitas Islam Sultan Agung, Central Java 50112, Indonesia (e-mail: rochman.mujayanto@unissula.ac.id).
\end{abstract}

\section{Clinical Manifestations}

Symptoms of SARS-CoV-2 infection include an upper respiratory tract infection (URTI) (mild-severe), ARDS, sepsis, and septic shock. ${ }^{7}$ Complaint of the oral cavity in COVID-19 patients in the form of mouth and throat pain due to tonsillitis, epiglottitis, or pharyngodynia. SARS-CoV-2 infection also causes inflammation of the nasopharynx region. ${ }^{9,10}$ Complaints of dry mouth and reduced taste sensation occur at a chronic stage. This condition occurs because a high SARS-CoV-2 viral load causes damage to the salivary glands. ${ }^{11}$ These complaints can be one indicator of patients suspected of being infected with SARS CoV-2. ${ }^{9-11}$

In COVID-19 patients, lesions were found in the skin and oral cavity. Skin lesions are exanthem (47\%), pseudo-chilblain (erythematous vesicles or erythematous pustules) (19\%), urticaria (19\%) vesicular eruption (9\%), and necrotic (6\%)..$^{12}$ Enanthem is the term exanthem in the oral mucosa. ${ }^{12-13}$ Exanthem is an erythematous rash that develops together with fever or together with a host of other symptoms. Exanthema lesions have morphological variations, including erythematous macules, erythematous papules, erythematous maculopapular, erythematous maculopapular accompanied by petechiae, erythematous vesicles, pustules with erythematous, and urticaria ${ }^{12-15}(\boldsymbol{\sim}$ Fig. 1 and $\boldsymbol{\imath}$ Table $\mathbf{1}$ ).

\section{Case Management}

To reduce pain in the oral cavity and inactivate coronavirus, an antiseptic mouthwash medication containing $0.2 \%$ iodine povidone is given. The ability of iodine povidone has been proven in the case of SARS-CoV and Middle East respiratory syndrome coronavirus (MERS CoV). ${ }^{8,9,17,18}$ Hydrogen peroxide $1 \%$ can be used as an alternative mouthwash, although no specific mechanism is known for deactivating coronavirus. ${ }^{8,9}$ Mouthwash containing chlorhexidine is not effective in COVID-19 cases. $^{9}$ Anti-inflammatory mouthwash can be used to reduce pain in the oral cavity, ${ }^{19-23}$ but the authors have not found a case report journal of this drug used in COVID-19 patients.

\footnotetext{
(C) 2020. European Journal of Dentistry.

This is an open access article published by Thieme under the terms of the Creative Commons Attribution-NonDerivative-NonCommercial-License, permitting copying and reproduction so long as the original work is given appropriate credit. Contents may not be used for commercial purposes, or adapted, remixed, transformed or built upon. (https://creativecommons.org/licenses/by-nc-nd/4.0/) Thieme Medical and Scientific Publishers Pvt. Ltd., A-12, 2nd Floor, Sector 2, Noida-201301 UP, India
} 

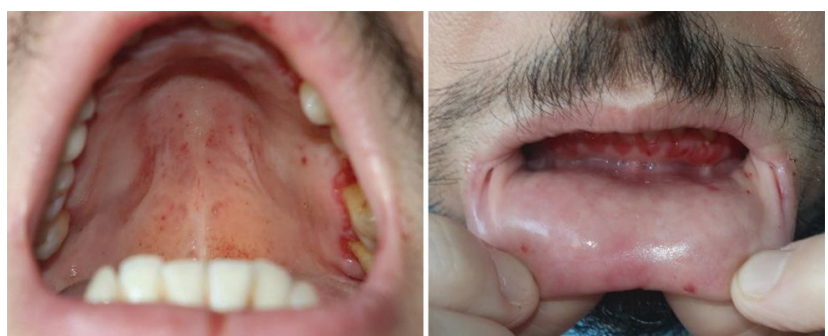

Table 2 Anti-inflammatory mouthwash

\begin{tabular}{|l|l|}
\hline Content of mouthwash & Work mechanism \\
\hline Benzydamine $\mathrm{HCl} 0.15 \% 19,20$ & Topical anesthetics \\
\hline Hyaluronic acid ${ }^{20-22}$ & Anti-inflammatory \\
\hline Zinc $^{19,22,23}$ & Anti-inflammatory \\
\hline Tetracycline $0.25 \%^{20}$ & Anti-inflammatory \\
\hline
\end{tabular}

Fig. 1 Enanthem lesions on palatal and labial mucosa accompanied by desquamation of gingival patients positive for COVID-19. ${ }^{12}$

Table 1 Differential diagnosis of COVID-19

\begin{tabular}{|c|c|c|}
\hline COVID-197,12 & Hand, foot, and mouth diseases ${ }^{15,16}$ & Measles $^{15,16}$ \\
\hline $\begin{array}{l}\text { - Fever }>38^{\circ} \mathrm{C} \\
\text { - Cough } \\
\text { - Throat pain } \\
\text { - Nasal congestion } \\
\text { - Malaise } \\
\text { - Maculopapular enanthem } \\
\text { - Skin lesions vary: } \\
\text { Exanthema } \\
\text { * Useudo-chilblain } \\
\text { * Necrotic } \\
\text { - Shortness of breath (moderate-severe } \\
\text { symptoms) }\end{array}$ & $\begin{array}{l}\text { - Fever }>38^{\circ} \mathrm{C} \\
\text { - Cough } \\
\text { - Anorexia } \\
\text { - Abdominal pain } \\
\text { - Pain in the throat and oral cavity } \\
\text { - Vesicular enanthem which ruptures into an } \\
\text { ulcer in the mucosa of the tongue, palate } \\
\text { - Vesicular exanthema on the palms, soles of } \\
\text { the feet }\end{array}$ & $\begin{array}{l}\text { - Fever }>38^{\circ} \mathrm{C} \\
\text { - Cough } \\
\text { - Conjunctivitis } \\
\text { - Coryza (runny nose) } \\
\text { - Koplik's spot enanthema (white } \\
\text { papules with erythematous around } \\
\text { them) } \\
\text { - Exanthema on the skin of the face } \\
\text { and neck, which then changes color } \\
\text { like copper }\end{array}$ \\
\hline
\end{tabular}

Abbreviation: COVID-19, coronavirus disease 2019.

\section{Disclosure}

History and understanding of clinical characteristics in the initial screening of patients with complaints of the intraoral are the starting points for COVID-19 identification.

\section{References}

1 Melo Neto CLM, Bannwart LC, de Melo Moreno AL, Goiato MC. SARS-CoV-2 and dentistry-review. Eur J Dent 2020;14(suppl S1):S130-S139 doi:10.1055/s-0040-1716438

2 Li X, Geng M, Peng Y, Meng L, Lu S. Molecular immune pathogenesis and diagnosis of COVID-19. J Pharm Anal 2020; 10(2):102-108 doi:10.1016/j.jpha.2020.03.001

3 Mason RJ. Pathogenesis of COVID-19 from a cell biology perspective. Eur Respir J 2020;55(4):9-11 doi:10.1183/13993003. 00607-2020

4 Wang C, Li W, Drabek D, et al. A human monoclonal antibody blocking SARS-CoV-2 infection. Nat Commun 2020;11(1):2251 doi:10.1038/s41467-020-16256-y

5 Morawska L, Cao J. Airborne transmission of SARS-CoV-2: The world should face the reality. Environ Int 2020;139:105730 doi:10.1016/j.envint.2020.105730

6 Sabino-Silva R, Jardim ACG, Siqueira WL. Coronavirus COVID-19 impacts to dentistry and potential salivary diagnosis. Clin Oral Investig 2020;24(4):1619-1621

7 Susilo A, Rumende CM, Pitoyo CW, et al. Coronavirus disease 2019: review of current literatures. JPDI 2020;7(1):45-67 doi:10.7454/jpdi.v7i1.415

8 Ather A, Patel B, Ruparel NB, Diogenes A, Hargreaves KM. Coronavirus disease 19 (COVID-19): Implications for clinical dental care. J Endod 2020 May;46(5):584-595. Doi: 10.1016/j. joen.2020.03.008
9 Meng L, Hua F, Bian Z. Coronavirus disease 2019 (COVID-19): emerging and future challenges for dental and oral medicine. J Dent Res 2020;99(5):481-487 doi:10.1177/0022034520914246

10 Lovato A, de Filippis C. Clinical presentation of COVID-19: a systematic review focusing on upper airway symptoms. Ear Nose Throat J 2020 Nov;99(9):569-576 doi:0.1177/ 0145561320920762

11 Chen L, Zhao J, Peng J, et al. Detection of SARS-CoV-2 in saliva and characterization of oral symptoms in COVID-19 patients. Cell Prolif 2020;53(12):e12923 doi:10.1111/cpr.12923

12 Galván Casas C, Català A, Carretero Hernández G, et al. Classification of the cutaneous manifestations of COVID-19: a rapid prospective nationwide consensus study in Spain with 375 cases. Br J Dermatol 2020;183(1):71-77 doi:10.1111/ bjd. 19163

13 Recalcati S. Cutaneous manifestations in COVID-19: a first perspective. J Eur Acad Dermatol Venereol 2020;34(5):e212-e213 doi:10.1111/jdv.16387

14 Drago F, Rampini E, Rebora A. Atypical exanthems: morphology and laboratory investigations may lead to an aetiological diagnosis in about 70\% of cases. Br J Dermatol 2002;147(2):255-260 doi:10.1046/j.1365-2133.2002.04826.x

15 Drago F, Ciccarese G, Gasparini G, et al. Contemporary infectious exanthems: an update. Future Microbiol 2017;12(2):171-193 doi:10.2217/fmb-2016-0147

16 Kadambari S, Segal S, Acute viral exanthems. Medicine 2017;45(12):788-793 doi:10.1016/j.mpmed.2017.09.011

17 Eggers M, Koburger-Janssen T, Eickmann M, Zorn J. In vitro bactericidal and virucidal efficacy of povidone-iodine gargle/mouthwash against respiratory and oral tract pathogens. Infect Dis Ther 2018;7(2):249-259 doi:10.1007/s40121-0180200-7 
18 Eggers M. Infectious disease management and control with povidone iodine. Infect Dis Ther 2019;8(4):581-593 doi:10.1007/s40121-019-00260-x

19 Farah B, Visintini S, Benzydamine for Acute Sore Throat: A Review of Clinical Effectiveness and Guidelines. 2018

20 Altenburg A, El-Haj N, Micheli C, Puttkammer M, AbdelNaser MB, Zouboulis CC. The treatment of chronic recurrent oral aphthous ulcers. Dtsch Arztebl Int 2014;111(40): 665-673 doi:10.3238/arztebl.2014.0665

21 Pignataro L, Marchisio P, Ibba T, Torretta S. Topically administered hyaluronic acid in the upper airway: a narrative review. Int J Immunopathol Pharmacol 2018;32:2058738418766739 doi: $10.1177 / 2058738418766739$
22 Dalessandri D, Zotti F, Laffranchi L, et al. Treatment of recurrent aphthous stomatitis (RAS; aphthae; canker sores) with a barrier forming mouth rinse or topical gel formulation containing hyaluronic acid: a retrospective clinical study. BMC Oral Health 2019;19(1):153

23 Mehdipour M, Taghavi Zenooz A, Sohrabi A, Gholizadeh N, Bahramian A, Jamali Z. A comparison of the effect of triamcinolone ointment and mouthwash with or without zinc on the healing process of aphthous stomatitis lesions. J Dent Res Dent Clin Dent Prospect 2016;10(2):87-91 doi:10.15171/ joddd.2016.014 